\title{
Keanekaragaman Jenis Dan Dominansi Mangrove Di Pesisir Pantai Desa Sehati Kecamatan Amahai, Kabupaten Maluku Tengah
}

\author{
Patricia Sipahelut $^{1}$, D. Wakano ${ }^{2}$, D. E. Sahertian ${ }^{3}$ \\ ${ }^{1}$ Mahasiswa Jurusan Biologi FMIPA, Unpatti \\ 2,3 Jurusan Biologi FMIPA, Unpatti \\ Jalan Ir. Putuhena, Kampus Unpatti, Poka, Ambon, Indonesia \\ E-mail: deli_wakano@gmal.com
}

\begin{abstract}
Abstrak: Secara geografis, Indonesia berada pada daerah tropis. Hal ini menyebabkan perairan Indonesia semakin kaya akan berbagai jenis biota-biota laut yang selalu ditemukan di perairan pesisir. Perairan pesisir merupakan tempat dimana ditemukan berbagai ekosistem yang tinggi produktivitas organiknya, salah satunya ialah mangrove. Mangrove adalah tumbuhan yang hidup di daerah pantai yang kehidupannya selalu dipengaruhi oleh arus pasang surut air laut. Penilitian ini akan menjelaskan bagaimana keanekaragaman jenis mangrove dan bagaimana dominansi jenis mangrove di pesisir pantai Desa Sehati Kecamatan Amahai, Kabupaten Maluku Tengah. Penelitian ini dilakukan untuk mengetahui keanekaragaman jenis dan dominansi jenis mangrove. Sehingga dari hasil penelitian ini menunjukan bahwa di perairan pantai Desa Sehati Kecamatan Amahai, Kabupaten Maluku Tengah ditemukan 5 jenis mangrove yaitu Rhizophora mucronata, Bruguiera cylindrica, Bruguiera gymnorhiza, Sonneratia alba dan Nypa fruticans yang merupakan anggota dari 2 kelas (Magnoliopsida dan Liliopsida), 2 ordo (Myrtales dan Arecales), 3 famili (Rhizophoraceae, Sonneratiaceae dan Arecaceae), dan 4 genus (Rhizophora, Bruguiera, Sonneratia dan Nypa) dengan indeks keanekaragaman jenisnya sedang dan dominansi jenisnya rendah.
\end{abstract}

\section{Kata Kunci: Mangrove, Keanekaragaman Jenis, Dominansi Jenis.}

Abstract: Geographically, Indonesia is in the tropics. This causes Indonesian waters to become increasingly rich in various types of marine biota which must be found in coastal waters. Coastal waters are places where various ecosystems with high organic productivity are found, one of which is mangrove. Mangroves are plants that live in coastal areas whose lives are always influenced by tidal currents. This study will explain how the diversity of mangroves and how the dominance of mangrove species on the coast of Sehati Village, Amahai District, Central Maluku Regency. This research was conducted to determine the species diversity and dominance of mangrove species. So that the results of this study show that in the coastal waters of Desa Sehati, Amahai Subdistrict, Central Maluku Regency, 5 mangrove species were found, namely Rhizophora mucronata, Bruguiera cylindrica, Bruguiera gymnorhiza, Sonneratia alba and Nypa 
fruticans which were members of 2 classes (Magnoliopsida and Liliopsida), 2 orders (Myrtales and Arecales), 3 families (Rhizophoraceae, Sonneratiaceae and Arecaceae), and 4 genera (Rhizophora, Bruguiera, Sonneratia and Nypa) with medium species diversity indexes and low species dominance.

\section{Key Words: Mangrove, Species Diversity, Species Dominance}

Secara geografis, posisi Indonesia berada pada daerah tropis dalam posisi silang antara Benua Asia dan Benua Australia. Posisi Indonesia juga berada di antara dua Samudera, Samudera Pasifik dan Samudera India. Diantara kedua samudera ini, terjadi pertukaran massa air di dalamnya yang mana karena hal ini sehingga menyebabkan perairan Indonesia semakin kaya akan berbagai jenis biota-biota laut yang biasanya biota-biota ini selalu ditemukan di perairan pesisir (Dharma, 1992). Perairan pesisir merupakan suatu tempat atau lingkungan yang memperoleh sinar matahari secara langsung yang cukup dan dapat menembus sampai kedasar perairan. Perairan pesisir juga kaya akan nutrient karena perairan mendapatkan banyak pasokan dari dua tempat yaitu darat dan lautan. Hal ini menyebabkan perairan merupakan tempat dimana ditemukan berbagai ekosistem yang tinggi produktivitas organiknya. Salah satu ekosistem yang tinggi produktivitas organiknya adalah mangrove.

Mangrove adalah masyarakat tumbuhan atau vegetasi tumbuhan yang ditemukan hidup di daerah pantai dan sekitar muara sungai yang kehidupannya selalu dipengaruhi oleh arus pasang surut air laut. Mangrove dapat tumbuh dengan baik pada pantai karang atau daratan terumbu karang yang berpasir tipis, atau pada pantai yang mempunyai jenis tanah alluvial, hal ini menyebabkan mangrove disebut sebagai tumbuhan pantai, tumbuhan pasang surut dan tumbuhan payau (Kordi, 2012).

Mangrove memiliki fungsi, antara lain fungsi fisik, biologis, dan ekonomi. Fungsi fisik mangrove yaitu untuk menjaga garis pantai agar tetap stabil, dan melindungi pantai dari erosi (abrasi) air laut, fungsi biologis yang dimiliki hutan mangrove antara lain sebagai daerah asuhan (nursery ground), daerah mencari makan (feeding ground), dan daerah pemijahan (spawning ground) dari berbagai biota laut sedangkan fungsi ekonomi sebagai sumber mata pencarian antara lain sumber bahan bakar (kayu), bahan bangunan (papan) serta bahan tekstil, obat-obatan dan makanan (Rahmawaty, 2006).

Akhir-akhir ini mangrove mengalami sangat banyak tekanan, baik secara langsung maupun tidak langsung. Tekanan secara langsung berupa pengaruh pasang surut air laut yang dapat menyebabkan tereksposnya mangrove, dan arus run off dari daratan dan hempasan gelombang laut yang dapat menyebabkan pengendapan sedimen yang berlebihan serta erosi atau abrasi.Masyarakat Desa Sehati umumnya sudah lama memanfaatkan mangrove untuk kehidupan sehari-hari diantaranya digunakan sebagai bahan bangunan, kayu bakar, bahan pembuat perahu, tempat mencari ikan, kepiting, kerang dan siput. Hal ini menyebabkan kawasan mangrove di Desa Sehati mengalami 
tekanan pada sisi biologis dimana pada kawasan ini kehidupan biota-biota laut seperti larva ikan, bivalvia, gastropoda, dan organisme laut lainnya akan terancam karena semakin berkurangnya mangrove sebagai tempat asuhan (nursery ground), tempat mencari makan (feeding ground), dan tempat pemijahan (spawning ground) bagi biotabiota tersebut. Mangrove pada desa Sehati mulai mengalami penurunan, terjadinya penurunan karena kurangnya pengetahuan masyarakat tentang pentingnya mangrove bagi kehidupan sehingga terjadi pengalihan fungsi mangrove oleh masyarakat setempat baik secara sengaja maupun tidak sengaja.

\section{METODE PENELITIAN}

Tipe penelitian ini bersifat deskriptif kuantitatif. Tipe penelitian ini bersifat deskriptif kuantitatif. Penelitian ini telah dilaksanankan di perairan pantai Desa Sehati Kecamatan Amahai, Kabupaten Maluku Tengah, pada bulan November sampai Desember 2018. Kemudian sampel mangrove di identifikasi pada Laboratorium Ekologi, Jurusan Biologi, Fakultas Matematika dan Ilmu Pengetahuan Alam, Universitas Pattimura. Alat yang digunakan dalam penelitian ini adalah thermometer, $\mathrm{pH}$ meter, refraktometer, taliarafia, kamera, meteran, buku tulis, alat tulis, buku identifikasi mangrove (Buku Panduan Mangrove di Indonesia, Rusila et al. 2006).

Bahan-bahan yang digunakan dalam penelitian ini adalah kantung plastik, kertas label, alkohol, tissue, sampel mangrove.Populasi dalam penelitian ini adalah semua jenis mangrove yang terdapat pada lokasi penelitian di Desa Sehati Kecamatan Amahai, Kabupaten Maluku Tengah. Dengan luas areal mangrove $29.700 \mathrm{~m}^{2}$ didapat dari $270 \mathrm{~m} \times$ $110 \mathrm{~m}$.

Pengambilan data dalam penelitian ini yakni melalui survey awal lokasi dengan menggunakan metode transek linear kuadrat yang bertujuan untuk menentukan jumlah transek. Lokasi yang dijadikan areal penelitian di Perairan Pantai Sehati yang berada di daerah pesisir Pantai Sehati Kecamatan Amahai, Kabupaten Maluku Tengah. Pengambilan sampel dilakukan pada air surut, dengan menggunakan metode transek linear kuadrat. Pada stasiun diletakkan 6 transek yang diletakkan secara tegak lurus mulai dari pasang tertinggi sampai dengan surut terendah dengan jarak antar transek $50 \mathrm{~m}$ dan jarak antar plot $10 \mathrm{~m}$. Pada tiap transek diletakkan plot pengamatan sebanyak 6 plot yang diletakkan secara berselang-selingdengan ukuran plot $10 \times 10$. Sampel mangrove yang dijumpai di dalam plot pengamatan, diambil bagian-bagian tumbuhan dari tiap jenis, kemudian dimasukkan kedalam kantung plastik bening yang telah diberi label sesuai untuk setiap titik dan plotnya.

\section{Pengukuran parameter fisik kimia}

Suhu air diukur pada setiap lokasi pengambilan sampel dengan menggunakan thermometer air raksa. Suhu air diukur dengan cara mencelupkan bagian reservoir kedalam air laut. Data suhu air laut dicatat setelah thermometer dibiarkan selama 2 menit. Salinitas air laut diukur dengan menggunakan refraktometer, dengan cara mengambil 
contoh air laut dan ditetesi pada bagian prisma. Nilai salinitas dapat dibaca melalui "Eyepiece". pH air laut diukur dengan pH meter, dengan cara mencelupakan elektroda pada $\mathrm{pH}$ meter kedalaman air laut dan nilai $\mathrm{pH}$ dapat dibaca pada skala $\mathrm{pH}$ meter.

\section{Identifikasi Sampel dan Analisa data}

Sampel mangrove yang ditemukan di lokasi penelitian diambil dan diidentifikasi menggunakan buku panduan pengenalan mangrove di Indonesia menurut (Rusila et al. 2006). Identifikasi sampel mangrove dilakukan dengan melihat bagian-bagian tumbuhan dari tiap jenis mangrove yang ditemukan pada lokasi penelitian. Sampel mangrove yang sudah diambil dan dimasukkan kedalam plastic sampel dan akan diidentifikasi lebih lanjut pada Laboratorium Ekologi FMIPA Universitas Pattimura Ambon. Setelah itu, dianalisis dengan menggunakan rumus keanekaragaman jenis dan dominansi.

Data yang dikumpulkan dianalisis dengan menggunakan indeks keanekaragaman dan indeks dominansi, meliputi:

\section{Indeks Keanekaragaman $\left(\boldsymbol{H}^{\prime}\right)$}

Keanekaragaman mangrove dihitung dengan menggunakan indeks keanekaragaman dari Shanon-Wiener yaitu:

$$
H^{\prime}=-\sum_{i=1}^{s} p i \ln p i
$$

Dimana:

$H^{\prime}=$ indeks keanekaragaman jenis mangrove

$p i=n i / N$

$n i=$ jumlah individu spesies ke $-\mathrm{i}$

$N=$ jumlah seluruh individu mangrove

$\ln =$ logaritma natur

Tabel 1. Indeks Keanekaragaman

\begin{tabular}{|l|l|}
\hline Nilai indeks keanekaragaman & $\begin{array}{l}\text { Keanekaragaman kecil, produktivitas sangat } \\
\text { rendah, indikasi adanya tekanan yang berat di } \\
\text { ekosistem tidak stabil }\end{array}$ \\
\hline $1,0<\mathrm{H}<3,322$ & $\begin{array}{l}\text { Keanekaragaman sedang, produktivitas cukup, } \\
\text { kondisi ekosistemcukup seimbang, tekanan } \\
\text { ekologis sedang. }\end{array}$ \\
\hline $\mathrm{H}>3,322$ & $\begin{array}{l}\text { Keanekaragaman tinggi, stabilitas ekosistem } \\
\text { mantap, produktivitas tinggi, tahan terhadap } \\
\text { tekanan ekologis }\end{array}$ \\
\hline
\end{tabular}

\section{Indeks dominansi}

Indeks dominansi menggambarkan komposisi spesies dalam komunitas. Dominansi spesies mangrove dihitung berdasarkan indeks Simpson dalam Fachrul (2007) yaitu: 


$$
\mathrm{D}=\sum_{i=1}^{s}(p i)^{2}
$$

Dimana:

$D=$ indeks dominansi

$p i=n i / N$

$n i=$ jumlah individu spesies ke-i

$N=$ total jumlah individu

Jika nilai $0,01<\mathrm{D} \leq 0,30$ maka dominansi rendah, jika $0,31<\mathrm{D} \leq 0,60$ maka dominansi sedang dan jika $0,61<\mathrm{C} \leq 1,00$ maka dominansi tinggi. Semakin besar indeks dominansi, semakin besar kecenderungan salah satu jenis yang mendominansi populasi.

\section{HASIL DAN PEMBAHASAN}

\section{Komposisi jenis mangrove yang ditemukan}

Mangrove yang ditemukan pada lokasi penelitian di perairan pantai Desa Sehati Kecamatan Amahai, Kabupaten Maluku Tengah berjumlah 276 individu yang termasuk dalam 2 kelas, 2 ordo, 3 famili, 4 genus dan 5 spesies yang tersaji pada tabel 2 .

Tabel 2. Komposisi jenis mangrove yang ditemukan di perairan pantai Desa Sehati Kecamatan Amahai, Kabupaten Maluku Tengah.

\begin{tabular}{|c|c|c|c|c|c|}
\hline Kelas & Ordo & Famili & Genus & Spesies & $\begin{array}{l}\text { Jumlahind } \\
\text { ividu }\end{array}$ \\
\hline \multirow{4}{*}{ Magnoliopsida } & \multirow{3}{*}{ Myrtales } & Rhizophoraceae & Rhizophora & $\begin{array}{l}\text { Rhizophora } \\
\text { mucronata }\end{array}$ & 108 \\
\hline & & & Bruguiera & $\begin{array}{l}\text { Bruguiera } \\
\text { clyndrica }\end{array}$ & 80 \\
\hline & & & & $\begin{array}{l}\text { Bruguiera } \\
\text { gymnorhiza }\end{array}$ & 61 \\
\hline & & Sonneratiaceae & Sonneratia & $\begin{array}{l}\text { Sonneratia } \\
\text { alba }\end{array}$ & 18 \\
\hline Liliopsida & Arecales & Arecaceae & Nypa & Nypa fruticans & 9 \\
\hline Total Individu & & & & & 276 \\
\hline
\end{tabular}

Dari hasil penelitian pada tabel 3 menunjukkan bahwa pada perairan pantai Desa Sehati Kecamatan Amahai, Kabupaten Maluku Tengah spesies yang paling banyak 
ditemukan adalah Rhizophora mucronata dari famili Rhizophoraceae yang berjumlah 108 individu, dan spesies yang palingsedikit ditemukan adalah Nypa fruticans dari famili Arecaceae yang berjumlah 9 individu.

\section{Deskripsi Morfologi Tumbuhan Mangrove}

\section{a Rhizophora mucronata}

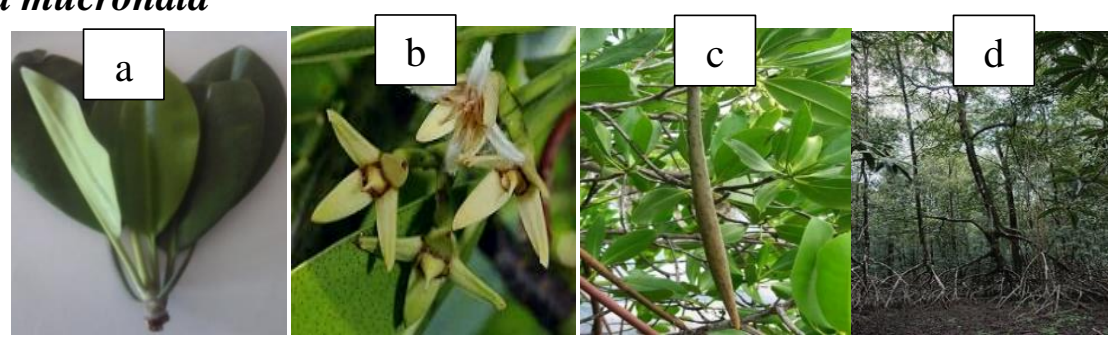

Gambar 1. Rhizophora mucronata, a) daun; b) bunga; c) buah; d) habitus (Sumber: Dokumentasi Pribadi)

Rhizophora mucronata memiliki daun yang tebal berwarna hijau cerah. Bentuk daunnya oval, panjang daun $16 \mathrm{~cm}$, lebar daun $9 \mathrm{~cm}$, ujung daunnya runcing, tidak ada jarak antar tangkai daun pada kuncup daun, pangkal daun runcing, dan memiliki pertulangan daun yang menyirip. Rhizophora mucronata memiliki batang yang berwarna gelap hingga hitam. Spesies ini memiliki jenis akar tunjang dan akar udara yang tumbuh dari percabangan bagian bawah. Rhizophora mucronata memiliki bunga majemuk, bunga memiliki 4 mahkota bunga berwarna putih dan 4 kelopak bunga berwarna kuning pucat. Spesies ini juga memiliki 8 benang sari dan 1 putik. Rhizophora mucronata memiliki buah yang panjang berukuran $29 \mathrm{~cm}$ berwarna hijau kecoklatan.

b Bruguiera cylindrica

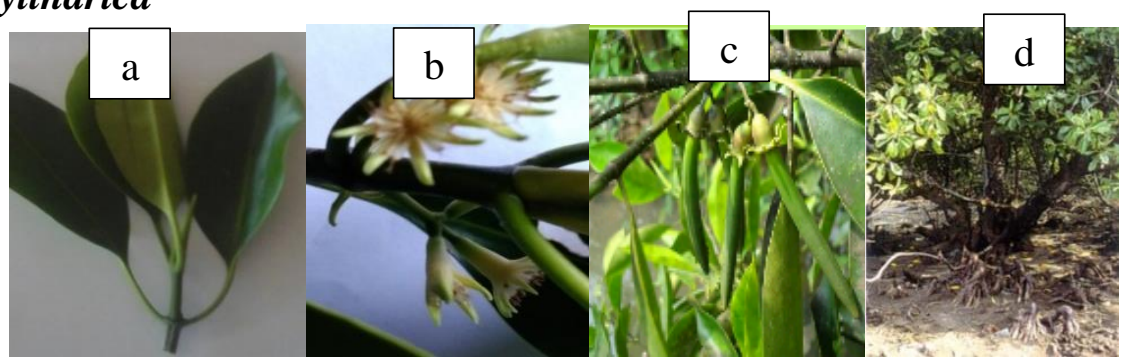

Gambar 2. Bruguiera cylindrica, a) daun; b) bunga; c) buah; d) habitus (Sumber: Dokumentasi Pribadi)

Bruguiera cylindrica memiliki daun yang tebal berwarna hijau cerah. Bentuk daunnya oval, panjang daun $17 \mathrm{~cm}$, lebar daun $7 \mathrm{~cm}$, ujung daun runcing, memiliki jarak antar tiap tangkai daun $5 \mathrm{~cm}$, pangkal daun runcing, dan pertulangan daunnya menyirip. Bruguiera cylindrica memiliki batang berwarna abu-abu dengan permukaan batang yang halus. Spesies ini memiliki jenis akar lutut dan akar papan yang melebar ke samping. Bruguiera cylindrica memiliki bunga majemuk. Bunga memiliki 8 mahkota bunga berwarna putih dan memiliki 8 kelopak bunga berwarna hijau kekuningan. Spesies ini juga memiliki 6 benang sari dan 1 putik. Bruguiera cylindrica memiliki buah yang panjang berukuran $25 \mathrm{~cm}$ berwarna hijau tua. 


\section{c Bruguiera gymnorhiza}

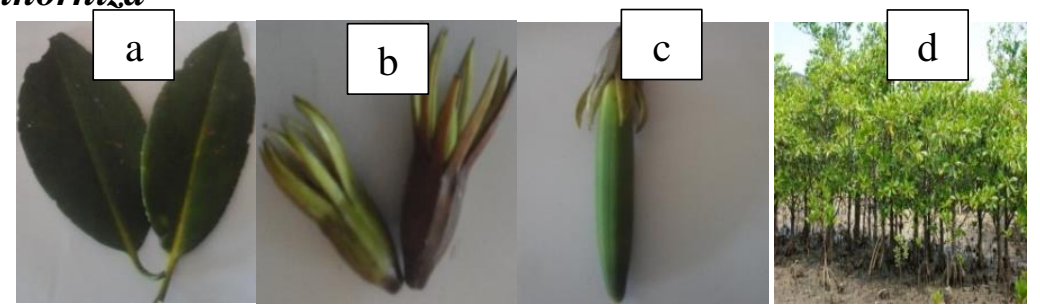

Gambar 3. Bruguiera gymnorhiza, a) daun; b) bunga; c) buah; d) habitus

(Sumber: Dokumentasi Pribadi)

Bruguiera gymnorhiza memiliki daun yang tebal berwarna hijau cerah, bentuk daun oval, panjang daun $20 \mathrm{~cm}$, lebar daun $12 \mathrm{~cm}$, ujung daun runcing, ada jarak antar tangkai daun pada kuncup daun $3,5 \mathrm{~cm}$, pangkal daun runcing, pertulangan daun menyirip. Bruguiera gymnorhiza memiliki batang yang berwarna abu-abu tua hingga kecoklatan. Spesies ini memiliki jenis akar tunjang dan mempunyai sejumlah akar lutut. Bruguiera gymnorhiza memiliki bunga tunggal. Bunga memiliki 11 mahkota bunga berwarna putih dan memiliki 11 kelopak berwarna merah. Spesies ini juga memiliki 6 benang sari dan 1 putik. Bruguiera gymnorhiza juga memiliki buah yang panjangnya 25 $\mathrm{cm}$ dan berwarna hijau.

\section{d Sonneratia alba}
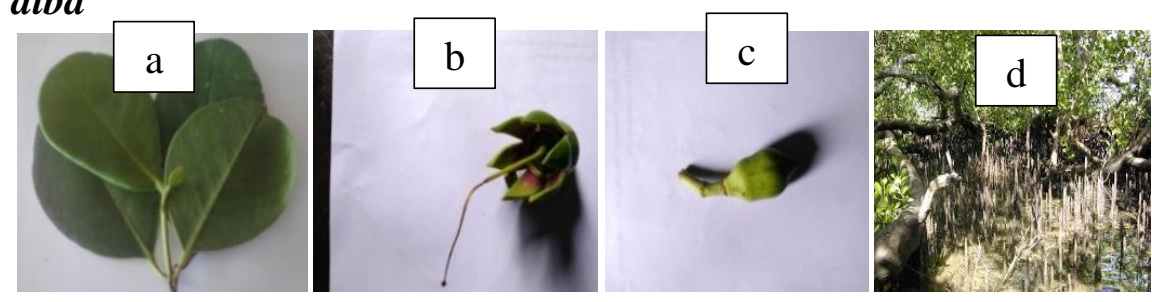

Gambar 4. Sonneratia alba, a) daun; b) bunga; c) buah; d) habitus

(Sumber: Dokumentasi Pribadi)

Sonneratia alba memiliki daun yang tebal berwarna hijau cerah. Bentuk daunnya bulat telur, panjang daun $13 \mathrm{~cm}$, lebar daun $8 \mathrm{~cm}$, ujung daun membundar, memiliki jarak antar tangkai daun $4 \mathrm{~cm}$, pertulangan daun menyirip. Sonneratia alba memiliki batang yang berwarna putih hingga coklat. Spesies ini memiliki jenis akar nafas. Sonneratia alba memiliki bunga tunggal. Bunga memiliki 6 mahkota bunga berwarna putih dan 6 kelopak bunga bagian luar berwarna hijau dan bagian dalam berwarna merah. Spesies ini juga memiliki benang sari yang banyak yang mudah rontok dan 1 putik. Buahnya berwarna hijau dengan panjang $4 \mathrm{~cm}$ berbentuk bulat. 


\section{e Nypa fruticans}

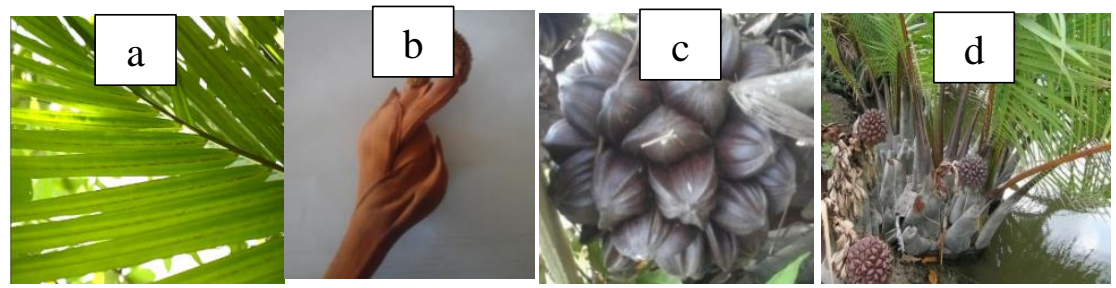

Gambar 5. Nypa fruticans, a) daun; b) bunga; c) buah; d) habitus

(Sumber: Dokumentasi Pribadi)

Nypa fruticans memiliki daun seperti susunan daun kelapa berwarna hijau. Bentuk daunnya lanset dengan panjang daun $25 \mathrm{~cm}$, lebar daun $2 \mathrm{~cm}$, ujung daun runcing, pertulangan daun sejajar. Nypa fruticans memiliki batang berwarna hijau hingga kecoklatan dan terdapat di bawah tanah. Spesies ini memiliki sistem perakaran yang kuat terhadap perubahan masukan air. Nypa fruticans memiliki bunga dengan 4 mahkota bunga berwana kuning hingga kecokelatan dan 4 kelopak bunga berwarna kuning. Nypa fruticans juga memiliki buah yang banyak dan berwarna cokelat hingga hitam.

\section{Indeks keanekaragaman jenis dan dominansi mangrove}

Dari hasil analisis beberapa indeks ekologi mangrove di perairan pantai Desa Sehati Kecamatan Amahai, Kabupaten Maluku Tengah dapat dilihat pada tabel 3.

Tabel 3. Indeks keanekaragaman jenis dan dominansi mangrove di perairan pantai desa Sehati Kecamatan Amahai, Kabupaten Maluku Tengah

\begin{tabular}{lll}
\hline Indeks Ekologi & Rata-Rata & Kriteria \\
\hline $\begin{array}{l}\text { Keanekaragaman } \\
\text { (H') }\end{array}$ & 1,345 & $\begin{array}{l}\text { Sedang, produktivitas cukup, kondisi } \\
\text { ekosistem cukup seimbang, dan tekanan } \\
\text { ekologis sedang }\end{array}$ \\
Dominansi (D) & 0,29 & Rendah
\end{tabular}

Pada tabel 3 terlihat bahwa indeks keanekaragaman spesies mangrove di perairan pantai Desa Sehati Kecamatan Amahai, Kabupaten Maluku Tengah memiliki nilai sebesar 1,345. Secara umum dapat dikatakan bahwa nilai keanekaragaman spesies mangrove di perairan pantai desa Sehati tergolong dalam kategori sedang, produktivitas cukup, kondisi ekosistem cukup seimbang dan tekanan ekologis sedang.

Indeks dominansi spesies mangrove di perairan pantai desa Sehati Kecamatan Amahai, Kabupaten Maluku Tengah mempunyai nilai rata-rata sebesar 0,29. Secara umum, nilai dominansi spesies mangrove di perairan pantai desa Sehati tidak terdapat spesies yang mendominasi spesies lainnya atau komunitas berada dalamkondisi yang stabil. 


\section{Parameter Fisik Kimia}

Hasil pengukuran faktor fisik kimia pada perairan pantai desa Sehati meliputi suhu, salinitas, $\mathrm{pH}$ dan substrat.

Tabel 4. Faktor fisik kimia lingkungan perairan desa Sehati Kecamatan Amahai, Kabupaten Maluku Tengah

\begin{tabular}{llc}
\hline No & Parameter & Hasil Pengukuran \\
\hline 1. & Suhu $\left({ }^{\circ} \mathrm{C}\right)$ & 30 \\
2. & Salinitas $(\%)$ & 23 \\
3. & $\mathrm{pH}$ & 7,0 \\
4. & Substrat & Berpasir dan pasir berlumpur \\
\hline
\end{tabular}

\section{KESIMPULAN}

Berdasarkan hasil penelitian maka dapat disimpulkan bahwa di perairan pantai Desa Sehati Kecamatan Amahai, Kabupaten Maluku Tengah ditemukan 5 jenis mangrove yaitu Rhizophora mucronata, Bruguiera cylindrica, Bruguiera gymnorhiza, Sonneratia alba dan Nypa fruticans yang merupakan anggota dari 2 kelas (Magnoliopsida dan Liliopsida), 2 ordo (Myrtales dan Arecales), 3 famili (Rhizophoraceae, Sonneratiaceae dan Arecaceae), dan 4 genus (Rhizophora, Bruguiera, Sonneratia dan Nypa). Ekosistem mangrove pada kawasan ini memiliki nilai keanekaragaman yang sedang dengan kondisi tidak ada spesies yang mendominansi atau komunitas berada dalam kondisi stabil.

\section{DAFTAR PUSTAKA}

Bengen. D.G. (2001). Pedoman Teknis Pengenalan dan Pengelolaan Ekosistem Mangrove Pusat Kajian Sumberdaya Pesisir dan Lautan. Institut Pertanian Bogor, Bogor.

Dahuri R. (2003). Keanekaragaman Hayati Laut. PT Gramedia Pusaka Utama. Jakarta Dewiyanti. (2004). Struktur Komunitas Moluska (Gastropoda dan Bivalvia) serta Asosiasinya pada Ekosistem Mangrove di Kawasan Pantai Ulee-Lheue, Banda Aceh, NAD. [Skripsi]. Program Studi Ilmu Kelautan. Fakultas Perikanan dan Ilmu Kelautan. Institut Pertanian Bogor. Bogor.

EffendiH. 2003. Telaah Kualitas Air Bagi Pengelolaan Sumberdaya dan Lingkungan Perairan. Kanisius. Yogyakarta.

Fachrul M. F. (2007). Metode Sampling Bioekologi. PT BumiAksara. Jakarta.

Harahab. (2010). Penilaian Ekonomi Ekosistem Hutan Mangrove dan Aplikasinya Dalam Perencanaan Wilayah Pesisir. Graha Ilmu. Yogyakarta. 
Heriyanto N. M dan E. Subiandono. (2012). Komposisidan Struktur Tegakan, Biomasa, dan Potensi Kandungan Karbon Hutan Mangrove diTaman Nasional Alas Purwo. Jurnal Penelitian Hutan dan Konervasi Alam, 9 (1); 023-032 .

IdrusA .A., Mertha, I. G., Hadiprayitno, G. Dan Ilhamdi, M. L. (2014). Kekhasan Morfologi Spesies Mangrove di Gili Sulat. Jurnal Biologi Tropis, 14 (2): 120-128. Istomo. (1992). Tinjauan Ekologi Hutan Mangrove dan Pemanfaatannya di Indonesia. Laboratorium Ekologi Hutan, Fakultas Kehutanan Institut Pertania Bogor. Bogor. Kementerian Negara dan Lingkungan Hidup. (2004). Baku Mutu Air Laut. Keputusan Kantor Menteri Negara Kependudukan dan Lingkungan Hidup. No. 51 (Kep. 02/MENKLH/I/1998) Tentang Pedoman Penetapan Baku Mutu Lingkungan. Jakarta.

Khazali. (2005). Panduan Teknik Penanaman Mangrove Bersama Masyarakat. Westlands International. Indonesia Program. Bogor.

Kordi K. dan Ghufran, H. (2012). Ekosistem Mangrove: Potensi, Fungsidan Pengelolaan. Rineka Cipta. Jakarta.

Kusmana, C., Onrizal dan Sudarmadji. (2003). Jenis-Jenis Pohon Mangrove di Teluk Bintuni Papua. Fakultas Kehutanan. Institut Pertanian Bogor dan PT Bintuni Utama Murni Wood Industries. Bogor.

NontjiA. (2007). Laut Nusantara. Intan Sejati. Klaten

Odum E.P., (1993). Dasar-dasar Ekologi. Edisi ke III. Terjemahan Tjahjono Saminga. Penerbit Gadjah Mada Press. Yogyakarta.

Puspayanti M. N., Andi, T. T, dan Samsurizal, M. S. (2013). Jenis-Jenis Tumbuhan Mangrove di Desa Lebo Kecamatan Parigi Kabupaten Parigi Mounting dan Pengembangannya Sebagai Media Pembelajaran. Jurnal e-Jipbiol 1 (1) : 1-9.

Rahmawaty. (2006). Upaya Pelestarian Mangrove Berdasarkan Pendekatan Masyarakat. Karya Tulis. Departemen Kehutanan Fakultas Pertanian Universitas Sumatera Utara. Medan.

RochanaE. (2010). Ekosistem Mangrove dan Pengelolaannya di Indonesia. www.irwantoshut.com. Diakses 07 Oktober 2010.

RochanaE. (2012). Ekosistem Mangrove dan Pengelolaannya di Indonesia. www.irwantoshut.com. Diakses 26 Januari 2015.

Romimohrtato K. (2001). Biologi Laut: Ilmu Pengetahuan Tentang Biota Laut. Penerbit Djambatan. Jakarta.

Rusila N.Y., M. Khazali, dan I.N.N. Suryadipura. (2006). Panduan Pengenalan Mangrove di Indonesia. Direktorat Jenderal Perlindungan Hutan dan Konservasi Alam. Wetlands International -Indonesia Programme. Bogor.

Silaen I.F., B. Hendrarto dan M. N. Supardjo. (2013). Distribusi dan Kelimpahan Gastropoda pada Hutan Mangrove Teluk Awur Jepara. Journal of Management of Aquatic Resources, 2 (3), 93-103. 
Supriharyono. (2000). Pelestarian dan Pengelolaan Sumberdaya Alam di Wilayah Pesisir Tropis. Gramedia. Jakarta

Suwardi E., Tambaru, Ambeng danD.Priosambodo. (2013). Keanekaragaman Jenis Mangrove Di Pulau Panikiang Kabupaten Barru, Sulawesi Selatan. Artikel JurusanBiologi FMIPA Universitas Hasanudin, Makasar. 1-9.

Suwondo, T. Febrita dan F. Sumanti. (2006). Struktur Komunitas Gastropoda pada Hutan Mangrove di Pulau Sipora Kabupaten Kepulauan Mentawi Sumatera Barat. Jurnal Biogenesis. Vol 2 (1): 25-29, 2005.

SyahputraR., Yandri F., dan Koenawan C. H. (2013). Struktur Komunitas Mangrove di Pulau Keter Tengah Kabupaten Bintan. e-Journal.com.

TalibF. M. (2008). Struktur dan Pola Zonasi (Sebaran Mangrove) serta Makrozoobentos yang Berkoeksistensi, di Desa Tanah Merah dan Oebelo Kecil Kabupaten Kupang. [Skripsi]. Program Studi Ilmu dan Teknologi Kelautan. Fakultas Perikanan dan Ilmu Kelautan. Institut Pertanian Bogor. Bogor

Welly M.,W. Sanjaya., I.N Sumerta dan D.N. Anom. (2010). Identifikasi Flora dan Fauna Mangrove Nusa Lembongan dan Nusa Cendingan. Balai Pengelolaan Hutan Mangrove. Jakarta. 